\title{
PERSEPSI KELAS MENENGAH MUSLIM TERHADAP DUAL BANKING SYSTEM DALAM MEMBENTUK KEKUATAN MEREK PERBANKAN SYARIAH
}

\author{
Lindiawatie, Muzdalifah \\ Program Studi Pendidikan Ekonomi, \\ Fakultas Ilmu Pendidikan dan Pengetahuan Sosial \\ Universitas Indraprasta PGRI Jakarta \\ Email : lindiawatie@ymail.com
}

\begin{abstract}
The goal of the research is knowing influence the perception of the dual banking system among the Middle Class of Moslems in forming the brand strength of Islamic Banking. The method is by taking data through the questionnaire in the East/South Jakarta and Depok on February to July 2016.Data analysis using simple linear regression by the amounting was 320 respondents. The results that there are influences the perception among the Middle Class of Moslems against the dual banking system in building brand strength of the Islamic Bank (IB), that is $19 \%\left(R^{2}\right)$. The brand strenght of "Islamic Bank (IB)" will be increased by $0.49 \%$ when the perception among the Middle Class of Moslems against the dual banking system increased by 1\%. Perception of The Middle Class of Moslem to the existence of the dual banking system in building brand strength Islamic Banking (IB) is positive with categories moderate $(0,436)$.
\end{abstract}

\section{Keywords : Perception, The Middle Class of Moslem, Dual Banking System, Brand}

\begin{abstract}
ABSTRAK
Penelitian ini bertujuan untuk mengetahui pengaruh persepsi kelas menengah Muslim Indonesia terhadap dual banking system dalam membentuk kekuatan merek perbankan syariah di Indonesia. Metode pengambilan data melalui kuesioner yang disebarkan pada 320 responden yang berlangsung pada Februari sampai dengan Juli 2016.Teknik analisis data menggunakan regresi linier sederhana. Hasil penelitian menunjukkan terdapat pengaruh persepsi kelas menengah Muslim terhadap dual banking system dalam membentuk kekuatan merek perbankan syariah sebesar $19 \%$, dengan korelasi tergolong positif dan sedang $(0,436)$. Kekuatan merek dari Islamic Bank (IB) "lebih dari sekedar bank" akan meningkat sebesar 0,49\% apabila persepsi kelas menengah Muslim terhadap dual banking system naik sebesar $1 \%$. Kesimpulan dari penelitian ini adalah persepsi kelas menengah Muslim Indonesia terhadap dual banking system dalam membentuk kekuatan merek perbankan syariah dikategorikan moderat atau sedang artinya pandangan kelas menengah muslim terhadap bank syariah yang tergabung dengan bank induk konvensional tidak menjadi persoalan bagi mereka.
\end{abstract}

Kata kunci : Persepsi, Kelas Menengah Muslim, Dual Banking System, Merek 


\section{PENDAHULUAN}

Perkembangan perbankan syariah mengalami kemajuan yang begitu pesat pada awal tahun 2000-an. Setelah 15 tahun berjalan, perkembangan perbankan syariah tidak mengalami perkembangan yang signifikan, bahkan cenderung mengalami laju penurunan pada akhir-akhir ini. Kenyataan tersebut berdasarkan penjelasan yang disampaikan oleh pimpinan bank pemerintah dan kepala Otoritas Jasa Keuangan sebagaimana dikutip dari Sindonews (2015), bahwa perkembangan perbanka syariah di Indonesia saatbini sedikitMarket share industri perbankan syariah terhadap industri perbankan nasional secara keseluruhan pada kuartal I 2015 masih minim, hanya sekitar $4,63 \%$ total aset perbankan syariah dari total aset perbankan nasional. Padahal pada tahun 2014 market share perbankan syariah sebesar 4,89\%. Melambatnya pertumbuhan industri perbankan syariah di Indonesia menyebabkan tertinggalnya perkembangan industri keuangan syariah di Indonesia jika dibandingkan dengan Malaysia yang mampu mencapai pangsa pasar di atas 20\%. Peneliti dari lembaga riset Center for Middle Class Consumer Studies (CMCS) sebagaimana dikutip dalam Republika Online (2014), melaporkan hasil kajiannya yang menyimpulkan bahwa pangsa pasar perbankan syariah tidak banyak bertambah karena gagal membangun kekuatan merek bank syariah.Yuswohady (2015: 89) menyatakan bahwa bank syariah tidak mampu membangun branding dan membuat kelas menengah muslim tertarik sehingga gagal mencapai pangsa pasar dan tidak mampu meningkatkan total asetnya sebesar 5\% dibandingan dengan total aset perbankan konvensional. Penyebab kegagalan tersebut menurut analisa Yuswohady dari CMCS adalah konsep bank syariah yang tanpa riba, sulit dirasakan oleh masyarakat sehingga sekilas masyarakat merasa diuntungkan dengan riba.

Studi dari CMCS menyimpulkan bahwa telah terjadi revolusi dalam pergeseran perilaku kelas menengah Muslim di Indonesia yang sangat mendasar selama 5 tahun terakhir. Ciriciri semakin makmur, religius dan cerdasnya masyarakat kelas menengah muslim di Indonesia ditandai dengan fakta berikut ini: banyaknya wanita berhijab, kebutuhan akan fashion dan kosmetik syariah, meningkatnya muda-mudi yang berumroh, munculnya hotel syariah, wisata syariah, gairah seni budaya Islam dan kepedulian terhadap makanan halal semakin meningkat. Gejala ini menunjukkan bahwa kelas menengah Muslim yang cerdas, makmur dan religius semakin tumbuh. Namun kenyataan itu tidak bisa diambil peluangnya oleh industri perbankan syariah.

Menurunnya pertumbuhan industri perbankan syariah dan tertinggalnya industri keuangan syariah Indonesia terutama perbankan jika dibandingkan dengan negara Malaysia menimbulkan ide dan usulan dari para praktisi yang telah berpengalaman dalam bidang manajemen perbankan syariahmenawarkan usulan dengan menetapkan kebijakan dual banking system kepada pemerintah dan regulator. Artinya, di setiap kantor cabang konvensional di Indonesia ada kantor resmi layanan bank syariah atau unit usaha syariahnya. Jika bank syariah sudah terpisah dari induknya (BUS), maka bank tersebut bisa membuka kantor cabang dengan satu area yang sama dengan induknya bank konvensional.

Di sisi lain kebijakan dual banking system ini sebenarnya menimbulkan masalah, karena perbankan syariah hanya menjadi bank kelas kedua dari bank konvensional. Oleh sebab itu kebijakan dual banking system ini menjadi dilema. Menurut pendapat praktisi, sistem ini menguntungkan bagi pengembangan bank syariah, tetapi di sisi lain sistem ini hanya menjadikan bank syariah sebagai bank kelas 2 sedangkan kelas utama adalah bank konvensional.Meskipun jangka waktu 3 windu telah berlangsung, namun perkembangan perbankan syariah tidak mengalami kemajuan signifikan padahal kenyataan menunjukkan bahwa selama kurun 5 tahun terakhir telah muncul kelas menengah Muslim yang mengalami revolusi perubahan pemikiran. Akan tetapi tampaknya perbankan syariah belum bisa menciptakan branding yang melekat di hati masyarakat banyak, khususnya kelas menengah Muslim.

Berdasarkan kenyataan tersebut, maka penulis tertarik untuk mengadakan penelitian tentang persepsi kelas menengah muslim terhadap dual banking system dalam membentuk kekuatan merek perbankan syariah dan apakah dualbanking system ini mampu membentuk kekuatan merek bagi bank syariah sehingga keberadaan dual banking system ini patut atau tidak dipertahankan guna 
meningkatkan pangsa pasar perbankan syariah supaya tidak terjebak pada perangkap pangsa pasar sebesar 5\% dan tidak menjadi bank kelas dua setelah bank konvensional.

Penelitian ini bertujuan untuk mengetahui persepsi kelas menengah Muslim terhadap dual banking system dalam membentuk kekuatan merek perbankan syariah dan mengetahui seberapa besar pengaruh persepsi kelas Menengah Muslim terhadap dual banking system dalam membentuk kekuatan merek perbankan syariah.Penelitian ini bermanfaat untuk kemajuan industri perbankan syariah di Indonesia yang mengalami penurunan drastis pada tahun 2015. Indikatornya berupa penurunan pangsa pasar perbankan syariah sebesar 4,5\% jika dibandingkan dengan tahun 2014 sebesar 4,89\%. Selain itu sejak bank syariah berdiri pada 1991 sampai sekarang (2015), sekitar 25 tahun berdiri, bank syariah belum bisa mencapai pangsa pasar di atas $5 \%$.

Manfaat hasil penelitian ini berupa sumbangan pemikiran dan saran yang berguna untuk para praktisi dan regulator yang berupaya untuk memajukan industri perbankan syariah di tanah air. Hasil penelitian dapat dijadikan landasan penetapan kebijakan untuk menentukan langkah yang tepat mengatur strategi dalam meraih pangsa pasar di atas 5\%, serta lebih cerdas dalam memanfaatkan peluang perubahan revolusi mendasar kelas menengah muslim Indonesia yang semakin cerdas, makmur dan religius.

Menurut Solihin (2010: 255), dual banking system merupakan penyelenggaraan sistem perbankan secara bersamaan yaitu bank konvensional dan bank syariah sekaligus. Dalam sistem perbankan ganda ini, kedua sistem perbankan secara sinergis bersama-sama memenuhi kebutuhan masyarakat akan produk dan jasa serta mendukung bagi sektor-sektor perekonomian. Kebijakan ini ditetapkan oleh pemerintah dalam UU No. 10 tahun 1998 yang merupakan perubahan UU No. 7 tahun 1992 tentang perbankan. Krisis moneter 1997-1998 menjadi latar belakang lahirnya Undang-Undang yang secara legal mengakomodir kegiatan perbankan umum menjalankan kegiatan perbankan berdasarkan prinsip syariah. Artinya bank konvensional dibolehkan menjalankan kegiatan bisnis yang berdasarkan prinsip syariah (tanpa bunga) bersama-sama dengan kegiatan bank umum (adanya bunga). Ketentuan tersebut dijelaskan sebagai berikut:
"Salah satu usaha bank umum adalah menyediakan pembiayaan dan atau melakukan kegiatan lain berdasarkan prinsip syariah sesuai dengan ketentuan yang telah ditetapkan oleh Bank Indonesia."(Pasal 6 Bab 3, Bagian Kedua UU No. 10 1998)

"Dalam memberikan kredit atau pembiayaan berdasarkan prinsip syariah, Bank Umum wajib mempunyai keyakinan berdasarkan analisis yang mendalam atau itikad baik dan kemampuan serta kesanggupan nasabah debitur untuk melunasi utangnya atau mengembalikan pembiayaan dimaksud sesuai dengan yang diperjanjikan (Pasal 8 Ayat 1, Bagian Kedua UU No.10 1998)

"Bank Umum wajib memiliki dan menerapkan pedoman perkreditan dan pembiayaan berdasarkan prinsip syariah, sesuai dengan ketentuan yang ditetapkan oleh Bank Indonesia."(Pasal 8 Ayat 2, Bagian Kedua UU No.10 1998)

Ketentuan itu menandai dimulainya era sistem perbankan ganda (dual banking system) di Indonesia, yaitu beroperasinya sistem perbankan konvensional dan sistem perbankan dengan prinsip bagi hasil. Dalam sistem perbankan ganda ini, kedua sistem perbankan secara sinergis dan bersama-sama memenuhi kebutuhan akan produk dan jasa perbankan, serta mendukung pembiayaan bagisektor-sektor perekonomian.

Selanjutnya melalui perubahan atas UU No. 7 Tahun 1992 Tentang Perbankan menjadi UU No. 10 Tahun 1998, keberadaan sistem perbankan syariah semakin didorong perkembangannya. Berdasarkan UU No. 10 Tahun 1998, Bank Umum Konvensional diperbolehkan untuk melakukan kegiatan usaha berdasarkan prinsip syariah, yaitu melalui pembukaan Unit Usaha Syariah (UUS). Dalam Undang-undang ini untuk pertama kalinya, nama "bank syariah" secara resmi digunakan menggantikan istilah "bank bagi hasil" yang telah digunakan sejak 1992. Data tahun 2015 menunjukkan bahwa saat ini terdapat 11 Bank Umum Syariah (BUS) dan 23 Unit Usaha Syariah (UUS).

Menurut Ascarya (2006), bank syariah adalah lembaga keuangan yang berfungsi memperlancar mekanisme ekonomi di sektor riil melalui aktivitas investasi atau jual-beli, serta memberikan pelayanan jasasimpanan/perbankan bagi para nasabah berdasarkan prinsip syariah, yaitu aturan perjanjian antara pihak bank dan 
pihak lain dalam penyimpanan atau pembiayaan yang sesuai dengan nilai-nilai syariah secara makro (keadilan, maslahah, sistem zakat, bebas bunga/riba, bebas spekulasi /perjudian dan bebas gharar/tidak jelas) dan mikro berupa sifat Nabi Muhammad SAW dalam berbisnis (jujur, menyampaikan, amanah dan profesional /kompeten).

Berikut perbedaan antara bank syariah dengan bank konvensional seperti tertera pada Tabel .1 berikut ini:

Tabel 1 Perbedaan Bank Syariah dengan Bank Konvensional

\begin{tabular}{|c|c|c|}
\hline & Bank Konvensional & Bank Syariah \\
\hline Fungsi dan kegiatan bank & $\begin{array}{l}\text { Intermediasi, jasa } \\
\text { keuangan }\end{array}$ & $\begin{array}{l}\text { Intermediasi, manager } \\
\text { investasi, investor, sosial, } \\
\text { jasa keuangan }\end{array}$ \\
\hline $\begin{array}{l}\text { Mekanisme dan obyek } \\
\text { usaha }\end{array}$ & $\begin{array}{l}\text { Tidak anti riba dan anti } \\
\text { maysir }\end{array}$ & Anti riba dan maysir \\
\hline Prinsip dasar operasi & $\begin{array}{l}\text { Bebas nilai (prinsip } \\
\text { materialis); } \\
\text { Uang sebagai komoditi; } \\
\text { Bunga. }\end{array}$ & $\begin{array}{l}\text { Tidak bebas nilai (prinsip } \\
\text { syariah Islam); } \\
\text { Uang sebagai alat tukar } \\
\text { dan bukan komoditi; } \\
\text { Bagi hasil, jual beli dan } \\
\text { sewa }\end{array}$ \\
\hline Prioritas pelayanan & Kepentingan pribadi & Kepentingan umum \\
\hline Orientasi & Keuntungan & $\begin{array}{l}\text { Tujuan sosial ekonomi dan } \\
\text { keuntungan }\end{array}$ \\
\hline Bentuk & Bank komersial & $\begin{array}{l}\text { Bank komersial, bank } \\
\text { pembangunan, bank } \\
\text { universal atau } \\
\text { multipurpose }\end{array}$ \\
\hline Evaluasi nasabah & $\begin{array}{l}\text { Kepastian pengembalian } \\
\text { pokok dan bunga }\end{array}$ & $\begin{array}{l}\text { Lebih hati-hati karena } \\
\text { partisipasi dalam risiko }\end{array}$ \\
\hline Hubungan nasabah & Terbatas debitur-kreditur & Erat sebagai mitra usaha \\
\hline $\begin{array}{l}\text { Sumber likuiditas jangka } \\
\text { pendek }\end{array}$ & Pasar uang, bank sentral & $\begin{array}{l}\text { Pasar uang syariah, bank } \\
\text { sentral }\end{array}$ \\
\hline Pinjaman yang diberikan & $\begin{array}{l}\text { Komersial dan non } \\
\text { komersial } \\
\text { Berorientasi laba }\end{array}$ & $\begin{array}{l}\text { Komersial dan non } \\
\text { komersial } \\
\text { berorientasi laba dan } \\
\text { nirlaba }\end{array}$ \\
\hline $\begin{array}{l}\text { Lembaga penyelesai } \\
\text { sengketa }\end{array}$ & Pengadilan, arbitrase & $\begin{array}{l}\text { Pengadilan, badan } \\
\text { arbitrase syariah nasional }\end{array}$ \\
\hline Risiko usaha & $\begin{array}{l}\text { Risiko bank tidak terkait } \\
\text { langsung debitur, risiko } \\
\text { debitur tidak terkait } \\
\text { langsung dengan bank } \\
\text { Kemungkinan terjadi } \\
\text { negative spread }\end{array}$ & $\begin{array}{l}\text { Dihadapi bersama antara } \\
\text { nasabah dan bank dengan } \\
\text { prinsip keadilan dan } \\
\text { kejujuran } \\
\text { Tidak mungkin terjadi } \\
\text { negative spread }\end{array}$ \\
\hline $\begin{array}{l}\text { Struktur organisasi } \\
\text { pengawas }\end{array}$ & Dewan komisaris & $\begin{array}{l}\text { Dewan komisaris, Dewan } \\
\text { pengawas syariah, Dewan } \\
\text { Syariah nasional }\end{array}$ \\
\hline Investasi & Halal atau haram & Halal \\
\hline
\end{tabular}

Pengertian kelas menengah menurut Laporan dari Oberman et .al yang diterbitkan oleh Mckinsey Global Institute (2012), adalah 
mereka yang memiliki pendapatan bersih di atas $\$ 3600$ per tahun. Kelas menengah ini tergolong consuming class. Mereka yang tergolong consuming class ini adalah mereka yang membelanjakan pendapatannya tidak hanya untuk memenuhi kebutuhan dasar sandang dan pangan saja tetapi mereka juga membelanjakan jenis-jenis barang dan jasa yang lain.Berdasarkan pengertian Asian Development Bank (ADB) dalam Salim (2012) kelas menengah Indonesia adalah mereka yang mengeluarkan pendapatan antara \$2-20 per hari. Kelompok ini di Indonesia terbagi menjadi 3, yaitu:

1) Lower middle class dengan pengeluaran ratarata \$ 2-4 per hari

2) Mid middle class dengan pengeluaran ratarata \$4-10 per hari

3) Upper middle class dengan pengeluaran ratarata $\$ 10-20$ per hari

Kelas menengah menurut Widiatmanti (2015) adalah kelas sosial ekonomi antara pekerja dan kelas atas, mereka meliputi para profesional, pekerja trampil, manajemen bawah dan menengah. Kelas menengah ini sering juga disebut consuming class karena kelas menengah dianggap mampu untuk membelanjakan lebih keuangannya.

Definisi merek dirumuskan dalam Undang-Undang Merek No. 15 Tahun 2001 pasal 1 ayat 1, yaitu : "tanda berupa gambar, nama, kata, huruf-huruf, angka-angka, susunan warna, atau kombinasi dari unsur-unsur tersebut yang memiliki daya pembeda dan digunakan dalam kegiatan perdagangan barang atau jasa." Dalam rancangan Undang-Undang Merek terbaru, cakupan definisi merek diperluas hingga mencakup pula bentuk, aroma, suara dan hologram (Tjiptono, 2014 : 90).Menurut Stratten dan Kramer (2014; 96), dalam membangun merek terdapat hal penting yang harus diperhatikan yaitu apa yang telah dilakukan oleh suatu institusi/lembaga dan bukan hanya sekedar pencitraan merek. Pencitraan merek tidak akan bernilai positif bagi konsumen apabila kenyataan yang dialami oleh konsumen tidak sesuai harapan.

\section{METODE}

Jenis penelitian ini adalah penelitian kuantitatif yang bersifat asosiatif yaitu penelitian yang bermaksud menguji hipotesis serta menunjukkan pengaruh antar variabel. Lokasi penelitian ini hanya dilakukan di wilayah wilayah Jakarta Timur/Selatan dan Depok. Penelitian dilaksanakan selama 6 bulan mulai bulan Februari sampai dengan Juli 2016.Pengambilan data dilakukan dengan cara menyebar kuesioner di wilayah Jakarta Timur/Selatan dan Depok. Penyebaran kuesioner ini bertujuan untuk memperoleh pemahaman dan sikap konsumen khususnya konsumen menengah Muslim yang bekerja dan beraktivitas di wilayah Jakarta Timur/Selatan dan Depok. Untuk mengetahui sikap dan pemahaman konsumen menggunakan skala Likert.

Populasi yang digunakan adalah seluruh penduduk Muslim di Indonesia. Dengan menggunakan definisi Asian Development Bank (ADB), penduduk yang masuk kategori kelas menengah adalah mereka yang memiliki pengeluaran antara 2-20 \$ per hari. Dengan kurs Rupiah terhadap Dolar USA sekarang ini sebesar $\mathrm{Rp} 13.700,-$, maka rata-rata pengeluaran penduduk kelas menengah tersebut berkisar antara $\mathrm{Rp} 27.400$ - Rp 274.000 per hari atau mereka yang memiliki penghasilan berkisar di antara Rp 10 juta sd 40 juta per tahunnya.

Cakupan penduduk dengan penghasilan yang dikategorikan kelas menengah ini meliputi banyak profesi antara lain dosen, PNS, TNI/Polri, para pegawai perusahaan, pekerja pabrik, dokter muda, paramedis dan pekerja di sektor informal misalnya kasir, pekerja di sektor ritel seperti manager toko dan lain-lain. Kelas menengah ini tidak termasuk wiraswasta/pengusaha atau pedagang.

Adapun sampelnya adalah penduduk Muslim yang berada pada kelas menengah yang disesuaikan dengan pendapatannya. Mengingat luasnya jenis profesi kelas menengah Muslim maka peneliti menggunakan teknik non probability sampling berdasarkan teknik convenience sampling, artinya teknik penentuan sampel berdasarkan kebetulan saja, anggota populasi yang ditemui dan bersedia menjadi responden untuk dijadikan sampel atau peneliti memilih orang-orang dekat saja. Penentuan sampel menggunakan pendekatan Isac Michael karena jumlah populasi khususnya kelas menengah Muslim tidak diketahui secara pasti (Siregar, 2014 : 34). Berdasarkan pendekatan tersebut diperoleh jumlah sampel adalah sebagai berikut (jumlah sampel dibulatkan menjadi 320 sampel): 

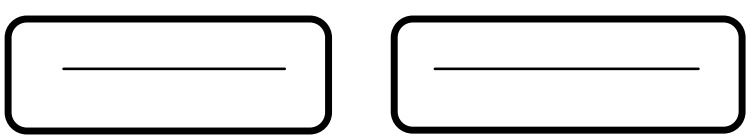

Keterangan : $n=$ jumlah sampel

$\mathrm{Z}=$ Tingkat kepercayaan

(95\%, distribusi normal 1,9)

$\mathrm{e}=$ perkiraan tingkat kesalahan $(5 \%)$

$\mathrm{p}=$ proporsi populasi

$q=1-p$

Variabel dalam penelitian ini terdiri atas 2 macam yaitu variabel bebas $(\mathrm{X})$ dan terikat $(\mathrm{Y})$. Variabel bebas adalah variabel Persepsi Kelas Menengah Muslim terhadap Dual Banking System (X), sedangkan variabel terikat adalah Kekuatan Merek Perbankan Syariah(Y). Sedangkan hiptesisnya adalah diduga terdapat pengaruh persepsi kelas menengah Muslim terhadap dual banking system dalam membentuk kekuatan merek perbankan syariah. Teknik analisis data menggunakan teknik analisis regresi linier sederhana dan uji t untuk menguji hipotesis.

\section{HASIL DAN PEMBAHASAN}

Karakteristik responden yang mengisi kuesioner meliputi mereka yang memiliki pendapatan yang tergolong pendapatan kelas menengah Muslim di Indonesia $(2-20$ US \$/per hari), baik laki-laki dan perempuan. Profesi responden didominasi oleh pekerja swasta dengan tingkatan pegawai paling awal (staf), selanjutnya ada juga guru dan dosen serta profesi lain-lain seperti PNS, buruh pabrik, pegawai toko, free lance dan lain-lain.

Peneliti juga berusaha mengetahui jenis rekening bank yang dimiliki mereka baik rekening yang berada di bank syariah, bank konvensional atau kedua jenis bank. Deskripsi responden terlihat pada gambar-gambar sebagai berikut:

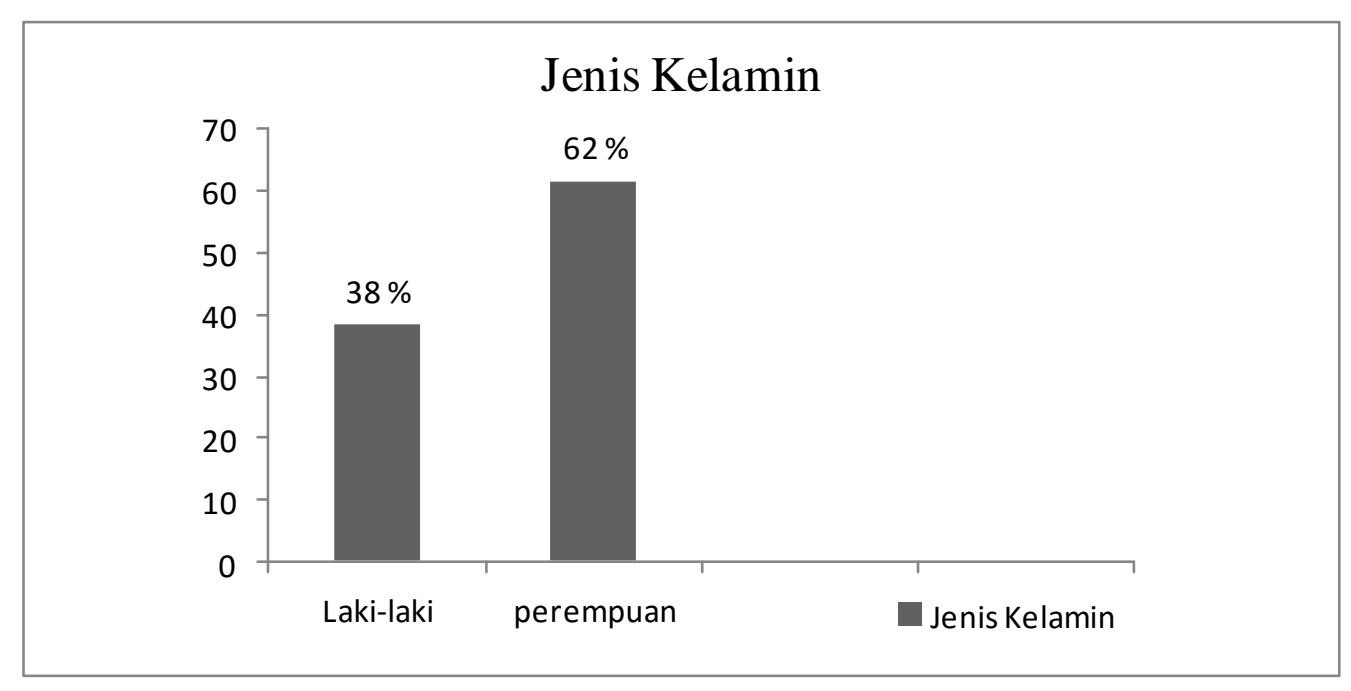

Gambar 1. Deskripsi Responden Berdasarkan Jenis kelamin

Berdasarkan gambar 1 jenis kelamin responden didominasi oleh responden yang berjenis kelamin perempuan sebesar $62 \%$ dan laki-laki sebesar $38 \%$. Jumlah penduduk perempuan secara statistik lebih banyak dibandingkan laki-laki. 


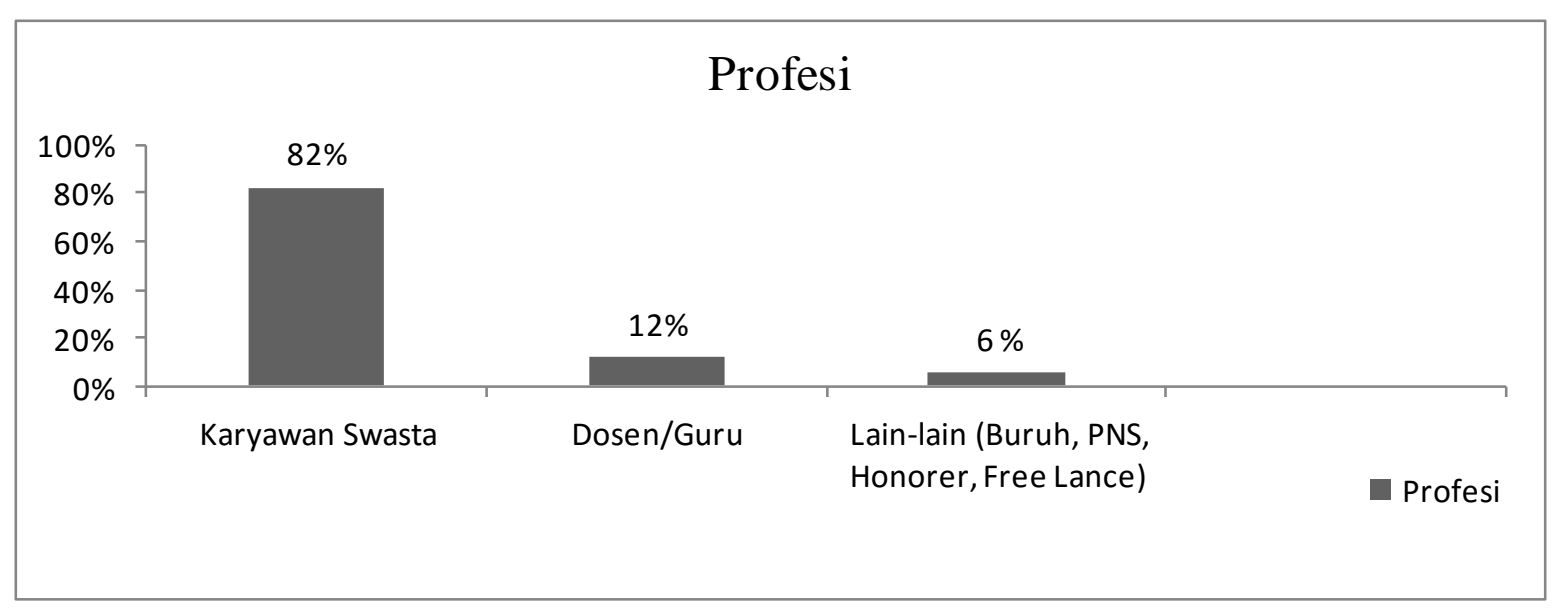

\section{Gambar 2. Deskripsi Responden Berdasarkan Pekerjaan}

Berdasarkan gambar 2 di atas pekerjaan responden didominasi oleh pekerja di sektor swasta dengan tingkatan staf atau pekerja pemula sebesar $82 \%$, selanjutnya guru dan dosen sebesar $12 \%$ terakhir profesi lain-lain sebesar $6 \%$ yang terdiri dari pekerja pabrik, PNS, honorer pada kementerian, free lance, konsultan dan lain-lain.

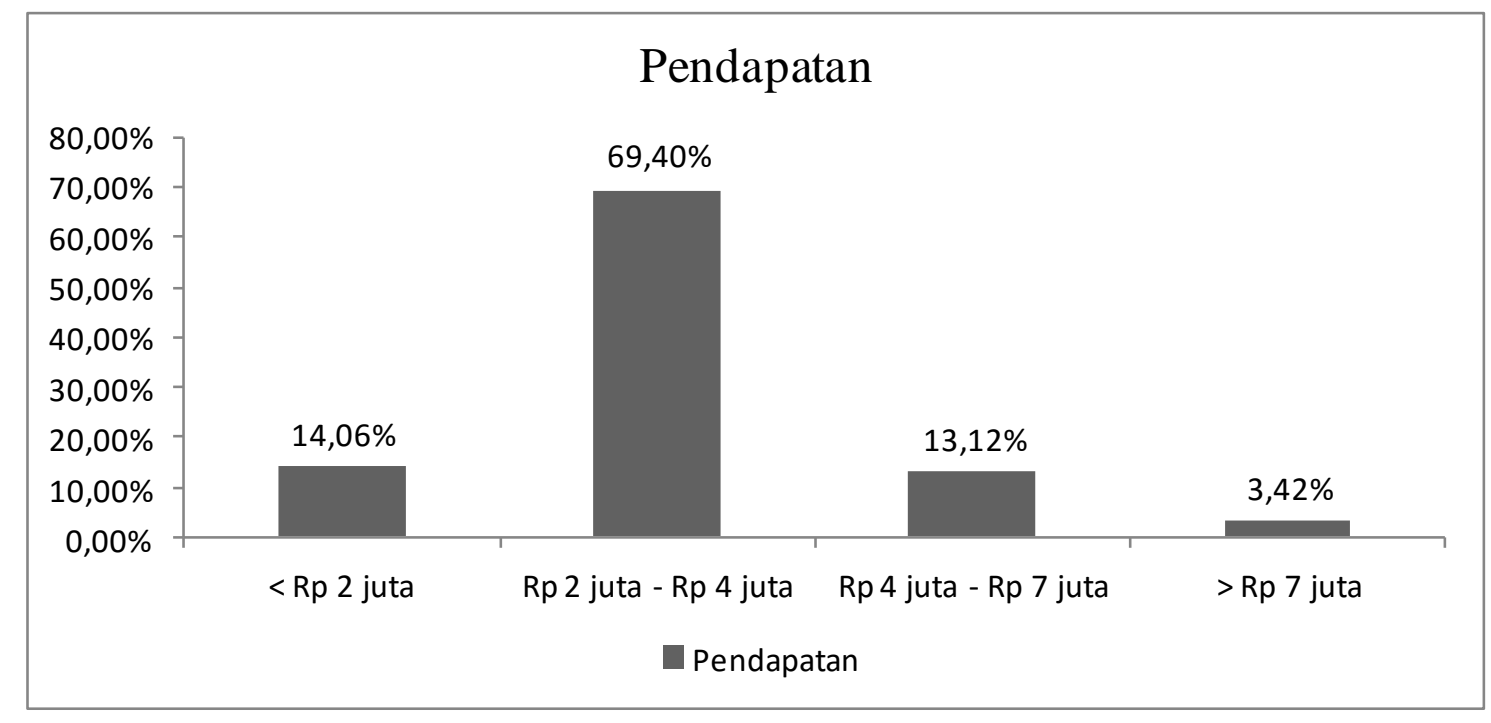

Gambar 3. Deskripsi Responden Berdasarkan Pendapatan

Berdasarkan gambar 3 di atas, berdasarkan pendapatannya peneliti membagi menjadi 4 kategori sebagai berikut:

1. Responden dengan pendapatan kurang dari Rp 2 juta sebesar 14,06

2. Responden dengan pendapatan antara $\mathrm{Rp} 2$ juta sampai dengan Rp 4 juta sebesar 69,4\%

3. Responden dengan pendapatan antara $\mathrm{Rp} 4$ juta sampai dengan Rp 7 juta sebesar 13,12 $\%$
4. Responden dengan pendapatan lebih dari Rp 7 juta sebesar 3,42\%

Berdasarkan nominal pendapatan tersebut diketahui bahwa seluruh responden merupakan penduduk kalangan menengah Muslim. Responden yang mendominasi adalah responden dengan pendapatan antara Rp 2 juta sampai dengan Rp 4 juta (mid middle). 


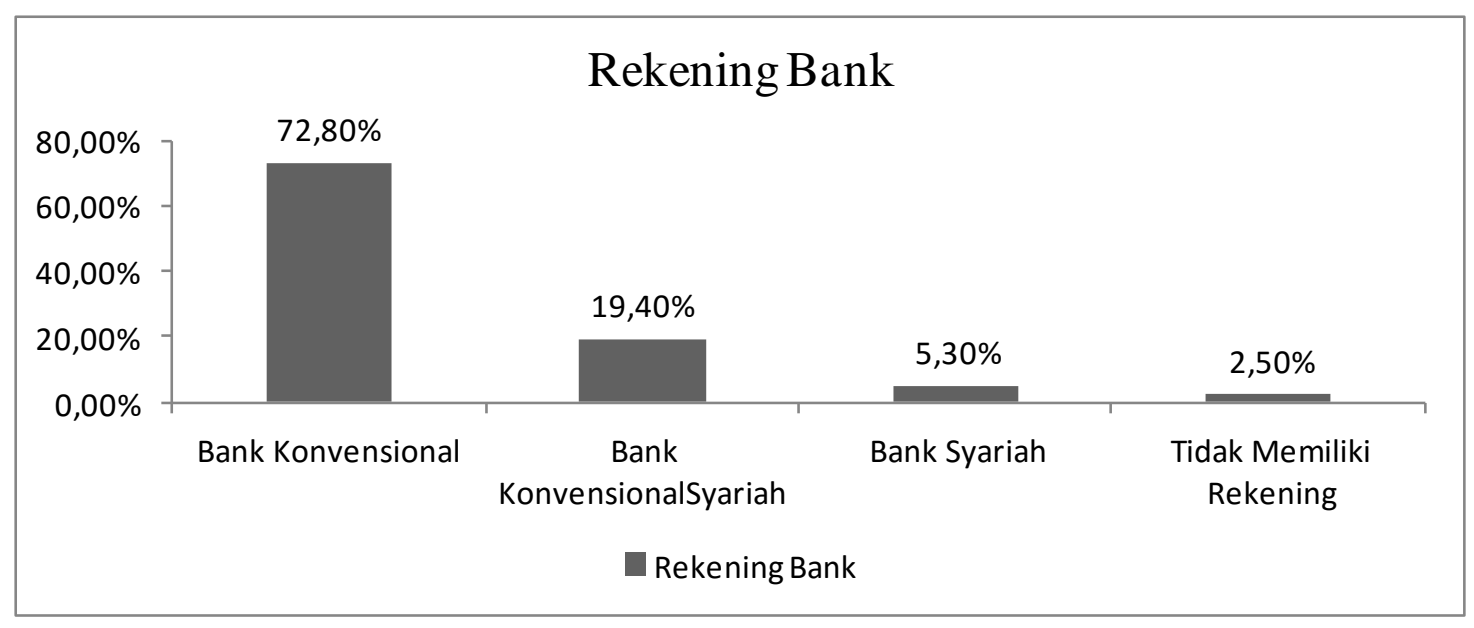

Gambar 4. Deskripsi Responden yang Memiliki Rekening Bank

Berdasarkan gambar 4 di atas, rekening bank yang paling banyak dimiliki oleh responden adalah rekening bank konvensional saja sebesar $72,8 \%$, responden yang memiliki rekening bank konvensional dan juga bank syariah sebesar $19,4 \%$, responden yang hanya memiliki rekening bank syariah saja sebesar 5,3 $\%$ dan responden yang tidak memiliki rekening bank sebesar $2,5 \%$.

Hasil pengisian kuesioner diperlihatkan pada Tabel 2 dan Tabel 3sSemua pernyataan dalam kuesioner yang dijadikan instrumen pengambilan data dalam penelitian ini telah dilakukan pengujian kesahihan (validitas) dan reliabilitas (konsistensi/keandalan). Semua pernyataan bersifat valid dan reliabel, artinya pernyataan-pernyataan dalam kuesioner adalah sahih dan dapat diandalkan. Total terdapat 20 pernyataan yang telah diisi oleh responden.

Tabel 2.

Pendapat, Sikap dan Pandangan Kalangan Menengah Muslim Terhadap Dual Banking System (X)

\begin{tabular}{|c|c|c|c|c|c|c|}
\hline \multirow[b]{2}{*}{ No } & \multirow[b]{2}{*}{ Pendapat, Sikap dan Pandangan } & \multicolumn{5}{|c|}{ Persentase (\%) } \\
\hline & & $\begin{array}{c}\text { STS } \\
(1)\end{array}$ & $\begin{array}{l}\text { TS } \\
(2)\end{array}$ & $\begin{array}{l}\mathbf{N} \\
(3)\end{array}$ & $\begin{array}{c}S \\
(4)\end{array}$ & SS (5) \\
\hline 1. & $\begin{array}{l}\text { Saya senang bank konvensional memiliki anak } \\
\text { usaha bank syariah/Unit usaha syariah (UUS) }\end{array}$ & 2,18 & 2,50 & 27,8 & 49,37 & 18,12 \\
\hline 2. & $\begin{array}{l}\text { Saya percaya bank syariah/Unit Usaha Syariah } \\
\text { bisa beroperasi dalam bank konvensional }\end{array}$ & 1.87 & 7,81 & 29,06 & 54,06 & 7,18 \\
\hline 3. & $\begin{array}{l}\text { Saya percaya anak usaha bank Syariah/UUS } \\
\text { dapat meningkat dengan cepat bila tumbuh } \\
\text { bersama bank induk yang konvensional }\end{array}$ & 2,18 & 7,50 & 39,06 & 42,81 & 8,43 \\
\hline 4. & $\begin{array}{l}\text { Saya percaya Bank syariah/Unit Usaha Syariah } \\
\text { lebih cepat dikenal oleh masyarakat jika } \\
\text { digandeng oleh bank konvensional }\end{array}$ & 2,50 & 7,50 & 30,62 & 44,37 & 15,00 \\
\hline 5. & $\begin{array}{l}\text { Saya percaya anak usaha Bank Syariah/Unit } \\
\text { Usaha Syariah kesulitan berkembang jika } \\
\text { memisahkan diri dari bank induk konvensional }\end{array}$ & 5,00 & $\begin{array}{l}27,8 \\
1\end{array}$ & 38,43 & 24,68 & 4,06 \\
\hline 6. & $\begin{array}{l}\text { Sebaiknya setiap orang memiliki rekening di } \\
\text { bank syariah dan bank konvensional sekaligus }\end{array}$ & 5,00 & $\begin{array}{l}23,4 \\
3\end{array}$ & 44,68 & 21,25 & 5,62 \\
\hline 7. & $\begin{array}{l}\text { Saya percaya lebih banyak untung daripada rugi } \\
\text { jika bank syariah/unit usaha syariah tumbuh }\end{array}$ & 2,5 & $\begin{array}{l}10,3 \\
1\end{array}$ & 50,93 & 31,87 & 4,37 \\
\hline
\end{tabular}




\begin{tabular}{lllllll}
\hline bersama bank induk yang konvensional & & & & & \\
\hline 8. & $\begin{array}{l}\text { Saya percaya bank syariah/anak usaha syariah } \\
\text { tidak bergantung sepenuhnya dengan bank induk } \\
\text { konvensional }\end{array}$ & 1,56 & 7,81 & 37,81 & 46,25 & 6,56 \\
\hline $\begin{array}{l}\text { Saya memilih menggunakan jasa bank } \\
\text { konvensional daripada anak usaha syariahnya } \\
\text { dalam semua transaksi }\end{array}$ & $\begin{array}{l}13,18,7 \\
5\end{array}$ & 51,25 & 28,12 & 4,68 \\
\hline 10. & $\begin{array}{l}\text { Saya percaya daya saing bank syariah/unit usaha } \\
\text { syariah rendah jika bersama bank konvensional }\end{array}$ & $\begin{array}{l}29,0 \\
6\end{array}$ & 42,81 & 20,93 & 5,31 \\
\hline
\end{tabular}

Sumber: Data diolah (2016)

Tabel 3.

Pendapat, Sikap dan Pandangan terhadap Kekuatan Merek Perbankan Syariah (Y)

\begin{tabular}{|c|c|c|c|c|c|c|}
\hline \multirow[b]{2}{*}{ No } & \multirow[b]{2}{*}{ Pendapat, Sikap dan Pandangan } & \multicolumn{5}{|c|}{ Persentase (\%) } \\
\hline & & $\begin{array}{c}\text { STS } \\
(1)\end{array}$ & TS (2) & $\begin{array}{l}\mathbf{N} \\
(3)\end{array}$ & $\begin{array}{c}S \\
(4)\end{array}$ & SS (5) \\
\hline 1. & $\begin{array}{l}\text { Saya menyadari dan mengetahui bahwa bank } \\
\text { konvensional memiliki Unit Usaha } \\
\text { Syariah/Divisi Syariah }\end{array}$ & 0,93 & 4,37 & 25,00 & 62,81 & 6,87 \\
\hline 2. & $\begin{array}{l}\text { Saya selalu memanfaatkan jasa pelayanan } \\
\text { Unit Usaha Syariah yang berada dalam bank } \\
\text { konvensional }\end{array}$ & 2,81 & 16,56 & 48,75 & 28,43 & 3,43 \\
\hline 3. & $\begin{array}{l}\text { Unit Usaha Syariah mampu menawarkan } \\
\text { beragam produk dan jasa yang lebih baik } \\
\text { daripada bank konvensional }\end{array}$ & 2,50 & 10,00 & 50,00 & 29,37 & 8,12 \\
\hline 4. & $\begin{array}{l}\text { Saya merasa aman dan nyaman bertransaksi } \\
\text { menggunakan jasa Unit Usaha Syariah atau } \\
\text { bank syariah }\end{array}$ & 1,25 & 6,87 & 40,00 & 40,31 & 11,56 \\
\hline 5. & $\begin{array}{l}\text { Saya bangga menggunakan jasa bank syariah } \\
\text { yang menjadi divisi dari bank konvensional }\end{array}$ & 1,56 & 3,12 & 50,93 & 36,25 & 8,12 \\
\hline 6. & $\begin{array}{l}\text { Unit Usaha Syariah memiliki perbedaan } \\
\text { prinsip dan operasional dengan bank induk } \\
\text { konvensional }\end{array}$ & 0 & 1,25 & 31,87 & 49,68 & 17,18 \\
\hline 7. & $\begin{array}{l}\text { Bunga bank konvensional tidak sama dengan } \\
\text { margin atau bagi hasil bank syariah }\end{array}$ & 0,93 & 2,18 & 42,50 & 46,25 & 8,12 \\
\hline 8. & $\begin{array}{l}\text { Saya puas apabila selesai bertransaksi di Unit } \\
\text { Usaha Syariah bank konvensional }\end{array}$ & 0,93 & 5,93 & 50,00 & 39,06 & 4,06 \\
\hline 9. & $\begin{array}{l}\text { Saya selalu mengharapkan dan membutuhkan } \\
\text { jasa perbankan yang sesuai prinsip syariah } \\
\text { dimana pun dan kapan pun }\end{array}$ & 1,87 & 3,43 & 39,37 & 39,68 & 15,62 \\
\hline 10. & $\begin{array}{l}\text { Bank syariah hadir untuk semua lapisan } \\
\text { masyarakat }\end{array}$ & 2,18 & 1,87 & 23,43 & 45,93 & 26,56 \\
\hline
\end{tabular}

Sumber : Data diolah (2016)

Tabel 4. Hasil Analisis Regresi Sederhana

\begin{tabular}{|c|c|c|c|}
\hline No & Jenis & Hasil & Interpretasi \\
\hline 1. & Model persamaan regresi & $Y=19,299+0,492 X$ & $\begin{array}{l}\text { a }=19,299 \text {, artinya apabila nilai } \\
\text { persepsi dual banking system } \\
\text { adalah 0 maka kekuatan merek } \\
\text { perbankan syariah sebesar } \\
19,299\end{array}$ \\
\hline & & & $\mathrm{b}=0,492$, artinya apabila \\
\hline
\end{tabular}




\begin{tabular}{|c|c|c|c|}
\hline & & & $\begin{array}{l}\text { persepsi dual banking system } \\
\text { naik } 1 \% \text {, maka kekuatan merek } \\
\text { perbankan syariah akan } \\
\text { meningkat sebesar } 0,49 \%\end{array}$ \\
\hline & Korelasi (R) & $\begin{array}{l}\mathrm{R}=0,436 \\
\text { (positif/sedang) }\end{array}$ & $\begin{array}{l}\text { Hubungan persepsi kalangan } \\
\text { menengah Muslim terhadap } \\
\text { dual banking system dalam } \\
\text { membentuk kekuatan merek } \\
\text { perbankan syariah adalah positif } \\
\text { dan sedang. }\end{array}$ \\
\hline
\end{tabular}

3. Koefisien determinasi $\left(\mathrm{R}^{2}\right) \quad \mathrm{R}^{2}=0,190$
Sebesar $19 \%$ faktor persepsi dual banking (X) mempengaruhi kekuatan merek perbankan syariah (Y)

\begin{tabular}{|c|c|c|c|}
\hline 4. & $\begin{array}{l}\text { Uji Signifikansi/hipotesis } \\
\text { (Uji t) } \\
\text { Kriteria: } \\
\text { Jika Sig } \leq \alpha \text {; Ho ditolak } \\
\text { Jika Sig } \geq \alpha \text {; Ho diterima } \\
\text { (Siregar, 2012: 300) }\end{array}$ & $\begin{array}{l}\text { Sig } 0,000<0,025 \text { (uji } \\
\text { dua sisi, } \alpha=5 \% \\
0,05 / 2=0,025 \\
\text { Hipotesis } 0 \text { ditolak) }\end{array}$ & $\begin{array}{l}\text { Terdapat pengaruh antara } \\
\text { persepsi kalangan menengah } \\
\text { Muslim terhadap dual banking } \\
\text { system dalam membentuk } \\
\text { kekuatan merek perbankan } \\
\text { syariah di Indonesia }\end{array}$ \\
\hline
\end{tabular}

Selama kurang lebih 25 tahun (19912016) sistem perbankan ganda dijalankan di Indonesia, sampai saat ini usaha untuk menarik kalangan menengah Muslim yang jumlahnya semakin bertambah untuk menjadi nasabah bank syariah baik yang menjadi unit/divisi bank konvensional atau bank syariah yang berdiri sendiri (BUS) tetap berlangsung melalui strategi-strategi yang dijalankan oleh OJK.

Namun berdasarkan hasil penelitian yang telah dilakukan oleh Penulis pada 2016, diketahui bahwa persepsi masyarakat kalangan menengah Muslim terhadap keberadaan unit usaha syariah di dalam bank konvensional hanya mempengaruhi sebesar $19 \%$ dalam upaya membangun atau membentuk image atau merek dalam pikiran masyarakat akan peran dan jasa perbankan syariah terhadap kegiatan ekonomi. Artinya pandangan "IB, Islamic Bank, lebih dari sekedar bank" belum bisa sepenuhnya membentuk pandangan yang kuat dalam masyarakat kalangan menengah Muslim yang jumlahnya semakin bertambah.

Kenyataan tersebut didapatkan dari hasil penelitian yang menunjukkan bahwa, sebagian besar responden yang diwakili oleh 320 responden memiliki rekening bank konvensional $(72,8 \%)$ dan hanya $5,3 \%$ yang memiliki rekening bank syariah saja. Sedangkan 19,4\% responden memiliki rekening di bank konvensional dan bank syariah sekaligus. Mereka yang memiliki kedua jenis rekening bank yang berbeda ini artinya menerima keberadaan bank syariah/unit usaha syariah tapi belum bisa beralih sepenuhnya sehingga masih mempercayakan aktivitas jasa bank konvensional.

Penelitian-penelitian sebelumnya yang terkait dengan perilaku konsumenpernah dilakukan oleh Bank Indonesiaa bekerjasama dengan Universitas Andalas yang meneliti tentang Identifikasi Faktor Penentu Keputusan Konsumen dalam Memilih Jasa Perbankan : Bank Syariah Vs Bank Konvensional." Hasil penelitian menyimpulkan bahwa sebesar $70 \%$ cenderung memilih bank konvensional dibanding bank syariah. Konsumen juga menilai bahwa produk kedua bank relatif sama artinya menurut konsumen karakteristik kedua bank relatif sama. Keunikan produk perbankan syariah yang ditawarkan selama ini tidak cukup untuk mempengaruhi persepsi konsumen terhadap keunikan bank syariah.Demikian juga bahwa penelitian-penelitian mengenai perilaku kelas menengah Indonesia dalam beberapa tahun ini telah banyak diteliti oleh lembaga seperti LIPI, Kementerian dan Universitas tentang kelas menengah di Indonesia. LIPI, Kementerian Pariwisata, Universitas seperti IPB dan Universitas Airlangga telah melakukan penelitian tentang gaya dan perilaku kelas Menengah di Indonesia dalam berbagai bidang seperti ekonomi, politik dan pariwisata. 
Sedangkan perbedaan penelitiaanpenelitian tersebut dengan penelitian ini adalah bahwa penelitian ini lebih menitikberatkan pada perilaku konsumen khususnya sikapkelas menengah Muslim Indonesia atas digabungnya operasional bank syariah ke dalam bank induk konvensional dengan istilah dual banking system, dimana merek yang dijadikan kekuatan oleh Bank Indonesia adalah pernyataan bahwa "Islamic Bank (IB), lebih dari sekedar bank," mampukah membuat kalangan kelas menengah Muslim tetap memilih bank syariah dibandingkan konvensional.

Penelitian ini menunjukkan bahwa dual banking system atau perbankan ganda belum sepenuhnya mampu membangun kekuatan IB sebagai lambang Islamic Bank, yang bermottokan "lebih dari sekedar bank", meski ada pengaruh persepsi masyarakat kalangan menengah Muslim terhadap keberadaan dual banking system dalam membangun kekuatan merek perbankan syariah. Akan tetapi hanya bernilai 0,49 saja, korelasinya pun tergolong sedang dan positif, yang bermakna tidak begitu kuat namun tidak juga lemah. Artinya persepsi masyarakat tentang dual banking system di masyarakat belum mengakar kuat dan menjangkau masyarakat kalangan menengah Muslim. Masyarakat menengah Muslim belum optimal merasakan manfaat dan kontribusi perbankan syariah dalam membangun perekonomian masyarakat.

Meski persepsi kalangan menengah Muslim ini hanya berkontribusi sebesar $19 \%$ dalam membangun kekuatan "Islamic bank (IB), lebih dari sekedar bank", namun jumlah ini pada dasarnya bisa ditingkatkan, karena apabila jumlah persentase setuju dan sangat setuju pada pernyataan-pernyataan yang membangun harapan positif dijumlahkan maka nilainya melebihi $50 \%$, artinya lebih dari separuh responden sebenarnya memiliki harapan yang relatif tinggi terhadap keberadaan dual bankingsystem menjadi tumbuh lebih baik dan besar. Pernyataan-pernyataan pandangan yang memiliki makna membangun harapan positif tersebut antara lain: Saya merasa aman dan nyaman bertransaksi menggunakan jasa Unit Usaha Syariah atau bank syariah dan Saya selalu mengharapkan dan membutuhkan jasa perbankan yang sesuai prinsip syariah dimana pun dan kapan pun. Masyarakat sebenarnya menginginkan perbankan syariah tumbuh besar dan mampu memberikan manfaat yang signifikan bagi mereka.
Berdasarkan penelitian ini dapat disimpulkan bahwa dual banking system belum optimal membangun merek yang mengakar dalam pikiran masyarakat kalangan menengah Muslim. Merek "Islamic Bank (IB), lebih dari sekedar bank" belum mampu secara signifikan mempengaruhi masyarakat untuk menggunakan dan mengambil manfaat dari jasa perbankan syariah yang berada dalam unit bank konvensional (UUS) ataupun yang berdiri sendiri dalam bentuk Bank Umum Syariah (BUS). Terbukti dari hasil penghitungan menggunakan analisis regresi sederhana bahwa nilai kekuatan merek perbankan syariah hanya naik sebesar $0,49 \%$ apabila terjadi kenaikan 1 $\%$ persepsi kalangan menengah Muslim terhadap dual banking. Dibuktikan juga dari hasil korelasi (R) yang bersifat sedang dan positif, selanjutnya $\mathrm{R}^{2}$ yang bernilai $19 \%$ yang berarti bahwa faktor persepsi dari kalangan menengah Muslim terhadap dual banking system dalam membangun kekuatan merek Islamic Bank (IB) hanya sebesar $19 \%$.

Akan tetapi dari hasil penelitian ini diketahui bahwa sebenarnya masyarakat kalangan menengah Muslim sangat berharap bahwa perbankan syariah dapat tumbuh meningkat secara signifikan dan mampu berperan dalam kehidupan sehari-hari mereka dimanapun dan kapan pun. Oleh sebab itu bank syariah harus bekerja lebih giat supaya bisa menjadi bank yang lebih baik dari semua aspek. Untuk bisa menjadi bank yang melekat di hati masyarakat dibutuhkan usaha yang ekstra keras.

\section{SIMPULAN DAN SARAN}

Persepsi kalangan menengah Muslim terhadap keberadaan dual banking system dalam membentuk kekuatan merek perbankan syariah di Indonesia adalah bernilai positif dan dapat dikategorikan sedang. Selanjutnya terdapat pengaruh sebesar $19 \%$ persepsi kalangan menengah Muslim terhadap dual banking system dalam membentuk kekuatan merek perbankan syariah di Indonesia. Nilai kekuatan merek perbankan syariah akan mengalami peningkatan sebesar $0,49 \%$ apabila terjadi peningkatan persepsi di kalangan menengah terhadap dual banking system. Dengan demikian dapat dikatakan bahwa pengaruh persepsi kelas menengah Muslim terhadap keberadaan dual banking system dalam membentuk kekuatan merek perbankan syariah adalah sedikit. Dengan kata lain keberadaan dual banking system dalam 
membentuk kekuatan merek perbankan syariah di kalangan menengah Muslim belum berjalan optimal.

Meskipun keberadaan dual bankingsystem dalam membentuk kekuatan merek perbankan syariah "Islamic Bank (IB), lebih dari sekedar bank", belum berjalan optimal selama 25 tahun berjalan (1991-2016), namun demikian masyarakat kalangan menengah Muslim menaruh harapan besar yang berupa keinginan untuk bisa bertransaksi dengan perbankan syariah baik Unit Usaha Syariah (UUS) atau pun Bank Umum Syariah (BUS) di mana pun dan kapan pun.

Mengingat keberadaan dual banking system belum berjalan optimal dalam membentuk kekuatan merek perbankan syariah di kalangan menengah Muslim, maka OJK dan perbankan syariah harus lebih agresif dan progresif menjaring jangkauan kalangan menengah Muslim yang tersebar dengan jumlah yang semakin meningkat. Perbankan syariah harus menjalin mitra dengan kalangan menengah Muslim yang umumnya didominasi oleh karyawan swasta, guru, dosen, PNS, karyawan kontrak dan lain-lain dengan jalan menjadi bagian dari kegiatan ekonomi yang dilaksanakan mereka di tempat mereka bekerja dan selalu mudah dibutuhkan di manapun berada.

Karena mereka menaruh harapan akan keinginan dan kemudahan mengakses perbankan syariah di mana pun dan kapan pun, maka perbankan syariah harus meningkatkan kualitas dan kuantitas teknologi jaringan informasi teknologi sehingga mampu bersaing dengan bank konvensional dan membawa merek perbankan syariah dengan lambang "Islamic Bank (IB), lebih dari sekedar bank," akan melekat kuat dalam benak masyarakat secara luas.

\section{REFERENSI}

Ascarya. (2006), Akad dan Produk Bank Syariah: Konsep dan Praktek di Beberapa Negara, Penerbit Bank Indonesia, Jakarta.

Kotler, P dan Kevin, L.K, (2009), Manajemen Pemasaran,Penerbit Erlangga, Jakarta.

Lovelock, C. dan Lauren, K.W. (2007), Manajemen Pemasaran Jasa, PT Indeks, Jakarta.

Oberman, Raoul et al. (2012), The Archipelago Economy: Unleashing Indonesia's Potential, McKinsey Global Institute.

Republika,"Sejarah Perkembangan Industri Perbankan di Indonesia." http://www.republika.co.id. 2008.

Salim, Felia. Indonesia's Middle Class. Dipresentasikan pada klub Finansial tentang Indonesa's Middle Class. Jakarta. 2012.

Schiffman, L. and Leslie, L.K. (2008). Perilaku Konsumen, Edisi ke 7, PT Indeks, Jakarta.

Siregar, S. (2014). Metode Penelitian Kuantitatif, Penerbit Kencana Prenadamedia Group, Jakarta.

Solihin, A.I.(2010). Buku Pintar Ekonomi Syariah, Penerbit Gramedia Pustaka Utama.

Stratten, S. and Alison, K. (2014). Unselling Pengalaman Baru Konsumen, Penerbit PT. Elex Media Komputindo, Kompas Gramedia, Jakarta.

Tjiptono, F. ( 2014). Branding \& Brand Longevity di Indonesia, Penerbit ANDI. Yogyakarta.

Tim Bank Indonesia dan Center for Banking Research(CBR) Universitas Andalas. "Identifikasi Faktor Penentu Keputusan Konsumen dalam Memilih Jasa Perbankan : Bank Syariah Vs Bank Konvensional", Penerbit Bank Indonesia, Jakarta, 2006.

Widiatmanti, Herru. "Artikel Penghasilan Kelas Menengah Naik = Potensi Pajak?" http://www.bppk.kemenkeu.go.id,2015.

Yuswohady, (2015), Marketing To The Middle Class Muslim, Edisi Revisi. Penerbit PT Gramedia Pustaka Utama. Jakarta. 